薬 物

\title{
口蓋扁桃摘出術術後の食事摂取量の比較
}

\author{
門田＼cjkstart舞 ・今井 貴夫*・伊東 真人* \\ 細川 清人*・花本＼cjkstart敦*
}

\section{Comparing Food Intake among Various Diets after Tonsillectomy}

\author{
Mai Kadota, Takao Imai, Mahito Ito, Kiyohito Hosokawa and Atsushi Hanamoto \\ (Kansai-Rosai Hospital)
}

\begin{abstract}
We compared caloric intake between liquid diet and Terumeal soft ${ }^{\circledR}$ (TERUMO) for two days after tonsillectomy. Terumeal soft is a paste type nutritious diet. Average caloric intake of iced Terumeal soft per day in one patient (704 kcal) was significantly higher than the average caloric intake of liquid diet (493 kcal). During this study, using a questionnaire survey, we compared the degree of pain and easiness of deglutition between patients eating liquid diet and patients eating Terumeal soft. We also compared the evaluations of taste and appearance between liquid diet and Terumeal soft. There was no significant difference in the degree of pain and easiness of deglutition between liquid diet and Terumeal soft. The evaluations of taste and appearance of Terumeal soft were significantly better than those of liquid diet. We concluded that the reason caloric intake of Terumeal soft was higher than that of liquid diet was that the taste and appearance were better, not that Terumeal soft decreased pain during eating or Terumeal soft was easier to deglute. The important thing that we should do to promote food intake by patients after tonsillectomy is to improve the taste and appearance of the food, rather than increasing the easiness of deglutition or decreasing the pain during eating. From this perspective, Terumeal soft is better than liquid diet for two days after tonsillectomy.
\end{abstract}

Key words : tonsillectomy, caloric intake, liquid diet, questionnaire survey, pain

はじめに

口蓋扁桃摘出術は耳鼻咽喉科の手術の中で最も頻繁に 行われる手術の一つである。㫶下第二相である咽頭期に おいては口蓋弓を形成する口蓋舌，口蓋咽頭筋の収縮が 起こるわけであるが，口蓋扁桃摘出術術後（以下，扁摘 後と略す）においてはこの時に最も術創が刺激されるこ とになり，スムーズに曣下が行えなくなる．扁摘後の食 事は軟らかいものより開始し，日が経つにつれ食事の硬 度を上げていくことが一般的である。曣下第二相は嚥下
運動の全過程でもっとも複雑な神経性調節が行われる時 期である．食塊の移動によって咽頭の知覚受容器が刺激 され求心性繊維を介し, 中枢へ神経衝撃が送り込まれる. 咽頭の知覚受容器への刺激が増せば嚥下が促進するとい う明らかなエビデンスはないが，より形のあるものの方 が物理的に嬩下しやすく扁摘後の食事としては形あるも のの方がよいという報告がある ${ }^{1)}$ ，疼痛に対しては硬度 の小さいものの方がよいが，鯂下のため咽頭の知覚受容 器を物理的に強く刺激するためには硬度の高いものの方 
がよく, 流動食よりは硬度が高いものの方がよい，寒冷 麻酔が扁摘後の疼痛を軽減させるという報告があり ${ }^{2)}$, 咽頭を冷却することは扁摘後の疼痛を軽減させる作用が あると考えられる．また，扁摘後患者を含む扁桃疾患患 者にかき氷摂取させることにより，起床時の疼痛が緩和 できたとの報告もある ${ }^{3)}$. カキ水はその硬度で咽頭の知 覚受容器は刺激しやすいが, 硬度が高すぎるため, 咽頭 に対する物理刺激が強く, 術後の咽頭粘膜を傷つける可 能性も多いに考えられる，そこでわれわれは，扁摘後の 食事時の疼痛を和らげ，なおかつ，咽頭の知覚受容器へ の刺激を高めるといら相反する条件を満たす食材とし て，ペースト状であり，なおかつ冷却しても凍らないテ ルミールソフト ${ }^{\circledR}$ (TERUMO) を当研究で取り上げた. われわれの施設では扁摘後の食事として術後 1 日目， 2 日目に流動食を出している. テルミールソフトの粘性度 は $20000 \mathrm{cP}$ であり，ネクター状飲料の 100 倍であること が報告されており4) テルミールソフトを嚥下する時の方 が流動食を與下する時よりも高い圧が咽頭内に生じ，咽 頭の知覚受容器を物理的により強く刺激する. 冷却した テルミールソフトが従来の扁摘後の食事である流動食に 比べ扁摘後の食事として優れているかどらかを，摂取力 ロリー量の比較, およびアンケート調査にて検討するこ とを当研究の目的とする.

\section{対象と方法}

当院では扁摘後 1 日目と 2 日目の食事として流動食を 出している，流動食に対し，テルミールソフトが扁摘後 の食事として優れているかどうかを比較検討した，摂取 カロリー量, およびわれわれが独自に開発したアンケー トにより，主観的な食事前の食欲，食べている時の痛み， 食べやすさ，味，見た目を検討した。 アンケートは表 1 〜 5 に示す.表 1 では空腹感のみについてたずねている. よってたとえば，食欲では空腹だが痛くて何も食べたく ないといった場合は，表 1 においては 4 を選択し，表 2 において 1 を選択することになる，表 $1 「 5$. 早く食べた い」は空腹すぎて何か早く食べないと気分が悪くなりそ 5，という意味であり，「4. 空腹」に比べ空腹感は上で ある. 平成 17 年 7 月 11 日より平成 18 年 3 月 20 日まで に当院にて口蓋扁桃摘出術を行った16歳以上の症例を当 研究対象とした. 当研究に対する, 関西労災病院臨床治 験倫理審查委員会での承認を得た。口蓋扁桃摘出術を行 う目的で当科へ入院した順番に 3 名ずつ, 術後の食事と
表 1 食事前の食欲

5. 早く食べたい

4. 空腹

3. 普通

2. 術後だから食べないといけないと思っている

1. 何も食べたくない

表 2 食べている時の痛み
5. 食べていない時より楽
4. 食べていない時と同じ
3. 食べていない時より少し痛い
2. 食べていない時よりかなり痛い
1. 食べたくなくなる程痛い

表 3 食べやすさ
5. 普段より食べやすい
4. 手術前と同じ
3. 術前より少し食べにくい
2. かららじて飲み込める
1. 飲み込めない

表 4 味
5. 普段でも食べたい

4. 術後の食事としてはおいしい

3. 普通

2. おいしくないが術後だから我慢して食べている

1. 食べられない

表 5 見た目

3. 食べたくなる

2. 普通

1. 食欲をなくす

してテルミールソフト，流動食を食べるよう依頼した。 入院日の決定は当院の耳鼻咽喉科医師が行うが，入院日 を決める際，すべての医師はその患者が術後，流動食を 食べることになるのかテルミールソフトを食べることに なるのか全く知らされていなかった．当研究に対する書 面による協力の同意を得たが，同意を得られなかった 5 名，および術後出血のため術翌日より絶飲絶食となった 2 名, 計 7 名を除外し, 術後食が流動食であった 13 名 (以下, 流動食群と呼ぶ), 術後食がテルミールソフトで 
あった 13 名 (以下, テルミールソフト群と呼ぶ), 計 26 名を当研究対象とした. 流動食の内容は日替わりである が 1 日のカロリーは約 $1000 \mathrm{kcal}$ に設定されている. 平成 17 年 7 月 13 日の当院での流動食を示す. 朝は $71 \mathrm{kcal} の$ 重湯, $32 \mathrm{kcal}$ の味噌スープ, $88 \mathrm{kcal}$ のリンゴ果汁, $134 \mathrm{kcal}$ の牛乳, 昼は $71 \mathrm{kcal}$ の重湯, $33 \mathrm{kcal}$ の味噌スープ, $220 \mathrm{kcal}$ のクリーム， $95 \mathrm{kcal}$ のリンゴ果汁， $49 \mathrm{kcal}$ のミルミル ${ }^{\circledR}$ (ヤクルト), 夕は $71 \mathrm{kcal}$ の重湯, $60 \mathrm{kcal}$ のスープ, $55 \mathrm{kcal}$ のくず湯, $134 \mathrm{kcal}$ の牛乳, 計 $1113 \mathrm{kcal}$ の食事であった. テルミールソフトとはその組成が 1 パックあたり容量 $125 \mathrm{~g}$, 熱量 $200 \mathrm{kcal}$ の栄養補助食品である. 1 パックに 蛋白質（乳清蛋白） $6.0 \mathrm{~g}$, 脂質（植物油） $6.0 \mathrm{~g}$, 糖質 (デキストリン，砂糖） $30.5 \mathrm{~g}$ ，水分 $80 \mathrm{~g}$ を含む．テル ミールソフト群には $-10^{\circ}$ の冷凍庫に 24 時間以上保存し ておいたテルミールソフトを扁摘後の食事として出し た. テルミールソフト群には一つ $200 \mathrm{kcal}$ であるイチゴ 味，もしくはヨーグルト味のテルミールソフトを各食に 一つずつ出した．テルミールソフトによる 1 日の総カロ リー量は $600 \mathrm{kcal}$ となるので, 流動食とカロリー量をあ わせるため, テルミールソフト群には総量 $200 \mathrm{ml}$, 総カ ロリー134 kcal の牛乳，もしくは総量 $200 \mathrm{ml}$, 総カロリー $91 \mathrm{kcal}$ のリンゴジュースを各食に 1 本ずつ追加した。 こ
れにより, テルミールソフト群に提供する 1 日の総カロ リー量は牛乳を追加した場合 $1002 \mathrm{kcal}$ ，リンゴジュース を追加した場合 $873 \mathrm{kcal}$ となった. 食事後, 流動食, も しくはテルミールソフト，牛乳（リンゴジュース）の残 量を耳鼻咽喉科病棟の看護師が計測し，摂取カロリ一量 を計算した．アンケートには術後 1 日目，2 日目に答え てもらったので, 流動食群, もしくはテルミールソフト 群からそれぞれ 1 項目につき $13 \times 2$, すなわち 26 の回答 が得られた。

当科では全例，全身麻酔下に口蓋扁桃摘出術を行って いる. 懸垂頭位もしくは頸部進展位でデービスの開口器 にて視野を確保し，前口蓋弓前縁を切開する．扁桃被膜 を確認し，これに沿って，粘膜剥離子，もしくはペアン 針子にて純的に剥離を進める．扁桃門付近まで剥離を進 めた後に, 絞断器にて切断, もしくは止血鈤子にて扁桃 門付近を把持し，切断した後に同部を結禁している。止 血はバイポーラを用いた電気凝固か絹糸による結紮止血 を行っている，術中出血の多い症例に対しては，扁桃窩 にアビテン®（ゼリア新薬工業株式会社）を留置し，前 後口蓋弓を縫合する.

有意差検定は $\chi^{2}$ 検定, および $\mathrm{t}$ 検定にて行った.

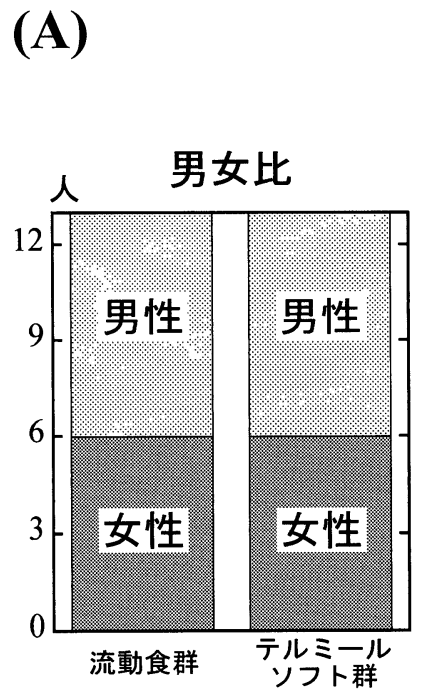

(B)

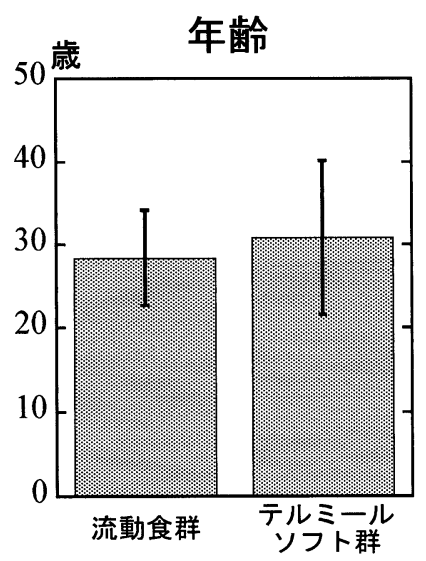

(C)
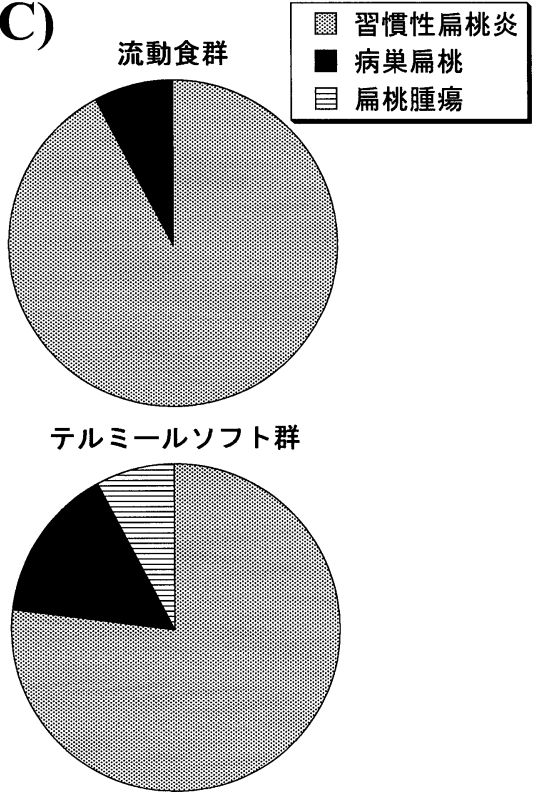

図 1 (A) 男女比

（B）平均年齢. エラーバーは標準偏差を表す.

(C) 口蓋扁桃摘出術を施行した疾患の内訳 


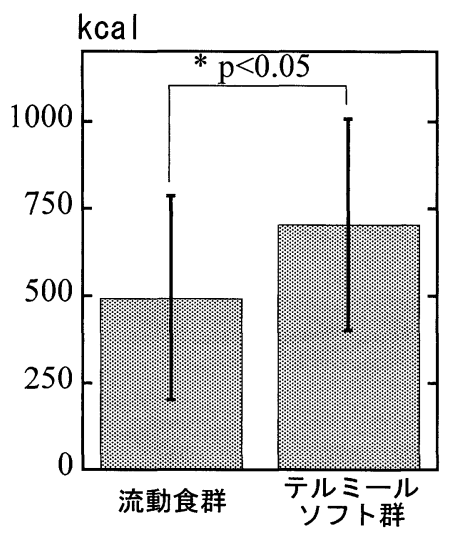

図 2 摂取カロリー量の平均値. エラーバーは標準偏差を表す. 両群間に有意差（ $\mathrm{p}<0.05 ）$ を認めた（ $\mathrm{p}=0.01365 ）$.

\section{結果}

流動食群は 16 歳〜 36 歳, 平均年齢 28.4 歳, 男 7 名, 女 6 名であった. テルミールソフト群は 19 歳〜 50 歳, 平均年齢 30.8 歳, 男 7 名, 女 6 名であった (図 $1 \mathrm{~A}, \mathrm{~B}$ ). 流動食群, テルミールソフト群における疾患の内訳を図 $1 \mathrm{C}$ に示す. 年齢, 男女比, 疾患の内訳において両群間 に有意な差は認めなかった。

図 2 に 1 日の摂取カロリー平均量を示す。流動食群は $493 \mathrm{Kcal}$ ，テルミールソフト群は $704 \mathrm{Kcal}$ であり，テル ミールソフト群の方が $\mathrm{t}$ 検定で有意 $(\mathrm{p}<0.05)$ に摂取カ ロリー量が多かった. アンケートによる両群の食事前の 食欲には $\chi^{2}$ 検定で有意差 $(\mathrm{p}<0.05)$ を認めなかった（図

\section{(A)}

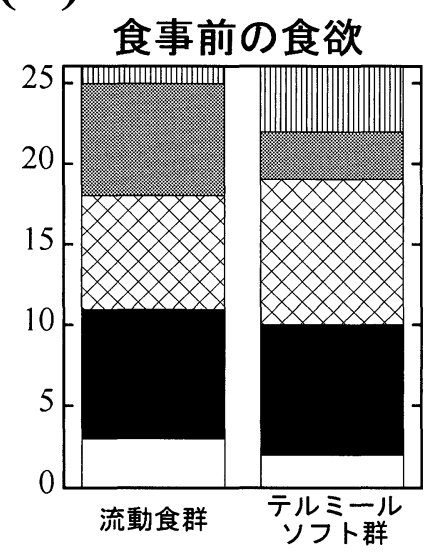

(D)

\section{(B)}

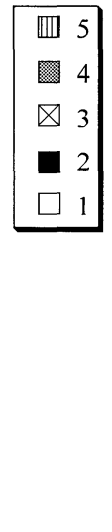

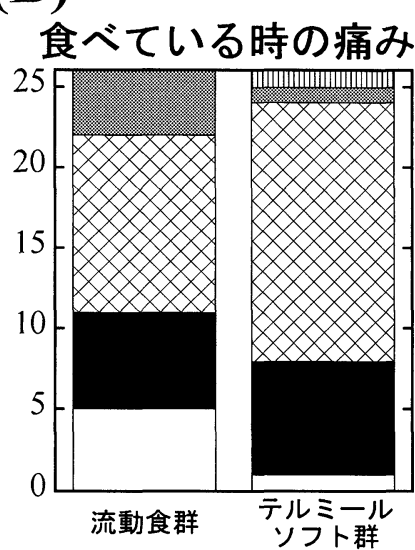

(C)

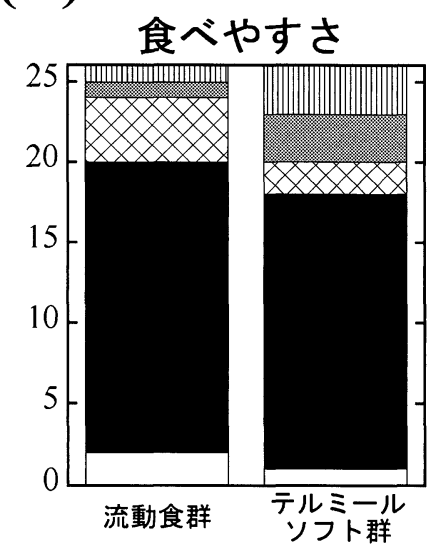

(E)

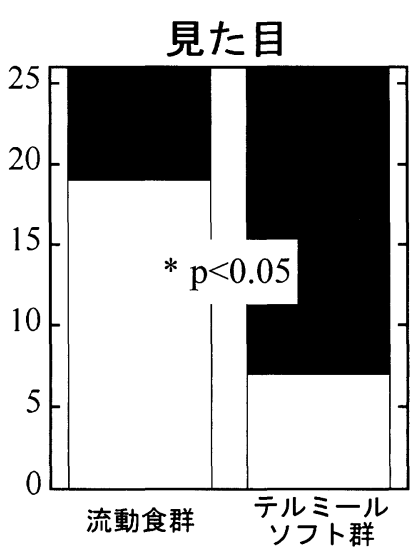

図 3 アンケート結果
(A) 食事前の食欲 $(\mathrm{p}=0.4267)$
(B) 食べている時の痛み $(\mathrm{p}=0.1667)$
(C) 食べやすさ $(\mathrm{p}=0.5531)$
(D) 味 $(\mathrm{p}=0.0043)$
(E) 見た目 $(p=0.0009)$
味および見た目に関し，両群間で有意差（p<0.05）を認めた。 
表 6 流動食の平均摂取量

\begin{tabular}{c|l|c}
\hline \hline \multirow{4}{*}{ 朝 } & 食事内容 & 平均摂取量 (\%) \\
\hline & 重湯 & 48 \\
\cline { 2 - 3 } & 味兽汁 & 55 \\
\cline { 2 - 3 } & 牛乳 & 37 \\
\cline { 2 - 3 } & リンゴジュース & 33 \\
\hline \multirow{5}{*}{ 昼 } & 重湯 & 41 \\
\cline { 2 - 3 } & ピューレ & 59 \\
\cline { 2 - 3 } & 葛湯 & 19 \\
\cline { 2 - 3 } & リンゴ果汁 & 55 \\
\cline { 2 - 3 } & ミルミル & 67 \\
\hline \multirow{5}{*}{ タ } & 重湯 & 51 \\
\cline { 2 - 3 } & スープ & 59 \\
\cline { 2 - 3 } & 葛湯 & 28 \\
\cline { 2 - 3 } & 牛乳 & 54
\end{tabular}

葛湯は昼 $19 \%$, 夜 $28 \%$ と他の流動食に比べ，摂取量が少な かった。

3A）。食事時の痛み，および食べやすさにも両群の間に 有意差（p<0.05）を認めなかった（図 $3 \mathrm{~B} ， \mathrm{C})$ 。味，お よび見た目には有意差（p<0.05）を認め（図 $3 \mathrm{D}, \mathrm{E})$, テルミールソフト群の方が流動食群に比べ，食事の味お よび見た目を高く評価していた。

流動食は各食に 4,5 種類の食事を出した。 それらの平 均摂取量を検討したところ, どの食事もほぼ $50 \%$ 程摂取 されていたが，葛湯のみ昼 19\%，夜 28\%と撕取量がきわ めて少なかった（表6).

\section{考察}

扁摘後患者は咽頭痛，嚥下痛のため術後数日は食事が 十分にとれない，扁摘後患者は基本的には消化器疾患が なく消化器症状がないので術後の食事の摂取カロリ一量 は 10〜30 歳代の青年期の 1 日必要エネルギーからする とかなり不足しがちであり, 空腹感は満たされない5).ま た疼痛があるにもかかわらず，食事をしなければならな いという苦痛が伴う。扁摘後の理想的な食事は食事中の 疼痛を軽減し，十分なカロリ一量が摂取できるものであ ると考えられる，扁摘後の食事の違いによる疼痛の違い を検討した研究がある。唾液量を増やし，疼痛を減らす ことを目的に扁摘後にチューイングガムをかませた研究 では，チューイングガムをかませなかった時と比べかま せた時の方が逆に，疼痛が増したという結果であった ${ }^{6)}$.
扁摘後にチューイングガムをかませることは疼痛の軽減 には役立たなかった。扁摘後に粗粘な食物を食べたグ ループ，軟らかい食物を食べたグループ，規則的に食べ るよう指示されただけのグループの 3 つグループ間で疼 痛を比較した研究ではこの 3 つのグループ間で鎮痛薬の 摂取量は軟らかい食物を食べたグループが一番多かった が, 疼痛のスコアには 3 群間で違いを認めなかった 例対象が 14 歳以下であるので, 今回のわれわれの研究と は症例対象が異なるが，行動制限，および食事を軟らか いものだけに制限したグループと，特に制限を設けな かったグループ間での疼痛を比較した研究ではこの $2 つ$ のグループ間での疼痛の違いは認められなかった ${ }^{8)}$. 従 来の研究結果と同じく，今回のわれわれの研究でも流動 食群とテルミールソフト群との間で，疼痛に関し，有意 な差を認めなかった。 $-20^{\circ} \mathrm{C}$ から $-32^{\circ} \mathrm{C}$ にて扁桃窩を 1 分冷却する寒冷麻酔により扁摘後の疼痛を軽減できた という報告があり ${ }^{2)}$ ，この報告にもとづき，今回われわ れはテルミールソフトを冷却することにより，そのよう な工夫を行わなかった流動食に対し，疼痛が軽減するこ とを期待したのであるが，寒冷麻酔程冷却できなかった ためか, 疼痛の軽減は観察されなかった。 以上より食事 内容の工夫で疼痛の軽減を図ることはきわめて困難と考 えられる。

より形のあるものの方が物理的に曣下しやすく扁摘後 の食事としては形あるものの方がよいという報告があ る11. 今回の研究において, テルミールソフトの方が流 動食に比べ，形があるので，燕下しやすいため，患者の 苦痛を減らすことができると考えたのであるが，アン ケートでの食べやすさに関し, 流動食群とテルミールソ フト群の間に有意差は認めなかった。 この原因として, 食事に形をつけることにより苝下時により高い曣下圧が 必要となり，口蓋咽頭筋の収縮がえ進し，扁摘後である ため口蓋咽頭筋の収縮による痛みが増したため食べやす いとは思わなかった，もしくは，テルミールソフトは冷 却することにより硬度は上昇しているが流動食に比べ燕 下を促進するほどの硬度を持っていなかった，というこ とが考えられる。

摂取カロリー量はテルミールソフト群の方が流動食群 に比へ，有意に高かった。扁摘後の食事内容の違いによ る摂取量を検討した研究はいくつか存在するが，摂取量 は全く食べていない，半分以下，半分以上等のスケール

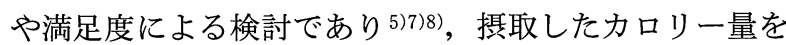


実際に測定し比較した研究は当研究以外ほとんどない. 当研究での両群間の年齢平均, 男女差, 疾患, 食前の食 欲に有意差を認めなかったので, 摂取カロリ一量の違い は食事内容の違いによるものと考えられる. アンケート 結果においてテルミールソフト群の方が流動食群に比 ベ，有意に勝っていたのは味，および見た目であった。 扁摘後のカロリー摂取量は食事中の痛みや食べやすさよ りも味や見た目という嗜好が影響していると考えられ る. 流動食群には, 各食で 4,5 種類の流動食を出してい るのだがそれらの平均損取量を検討したところ, 葛湯の 拱取量がきわめて少なかった（表 6). 葛湯が葛湯以外の 流動食に比べ燕下が困難であったとは考えがたく, 葛湯 の摂取量が少なかったのは味が原因であったと考えら れ，この結果からも味は重要であると考えられる.

片山 ${ }^{9)}$ は，本来楽しむべきである食事が患者にとって 苦痛とならないよう, できるだけ満足感が得られるよう 援助していくことの必要性を述べている. 従来の研究結 果, および当研究結果により食事の内容で疼痛を軽減さ せること，また，食べやすさを向上させることはきわめ て困難であると考元られる，扁摘後に摂取した食事量が 多い方が術後出血のリスクを減らせる可能性が示唆され ており7), 扁摘後患者に十分なカロリー量を摂取しても らい空腹感をなくし, また, 術後の創傷治癒を促し, 術 後出血のリスクを減らすためにもわれわれにとって実行 可能であることは疼痛を軽隇することや食べやすさを向 上させるよう工夫することよりもむしろ，味および見た 目のよい食事を提供することであると考えられる。この 点において, 当研究により, 扁摘後の 1 日目, 2 日目の 食事としては流動食よりもテルミールソフトの方が優れ ていることが示された。

\section{まとめ}

1）口蓋扁桃摘出術を行った 26 例に対し，13 例には術 後流動食を出し, 13 例にはテルミールソフトを出した。 それらのカロリー摂取量を測定し, 食事に対するアン ケート調查を行った。

2）テルミールソフトを食した群の方が流動食を食し た群に比ベ，カロリー摂取量は有意に高かった。

3）アンケート調查ではテルミールソフトの方が流動 食に比べ, 味, 見た目が有意に勝っていた。痛み, 食べ
やすさにおいては両者間に有意差を認めなかった。

4）口蓋扁桃摘出術術後の食事に関し, 食事内容にて食 ベている時の痛みや食べやすさをコントロールするのは 困難である，そこで拱取カロリ一量をあげるためには食 事の味や見た目をよくするべきであると考えられた。 こ の点において, テルミールソフトは流動食よりも口蓋扁 桃摘出術術後 1 日目, および 2 日目の食事として優れて いると考元られた。

\section{謝 辞}

当研究に対し多大な御理解, 御協力をいただいた関西労災病 院南七階病棟看護師一同に深謝いたします.

\section{参考文献}

1) Talbot $\mathrm{H}$ : Adenotonsillectomy, technique, and postperative care. Laryngoscope $62: 1877 \sim 1892,1965$.

2) Robinson SR and Purdie GL : Reducing post-tonsillectomy pain with cryoanalgesia: a randomized controlled trial. Laryngoscope $110: 1128 \sim 1131,2000$.

3）安藤知可子, 傍島由佳, 島田尚美, 他：扁桃疾患患者に対 する起床時疼痛緩和の有用性一かき氷摂取を試みて一. 三 室病看誌 $20: 31 \sim 33,2004$.

4) 合田文則：半固形化学養剂（食品）による胃瘦加らの短時 間注入法. 臨栄 $106: 757 \sim 762,2005$.

5）佐藤百合子, 市村美紀子, 阿部とし子, 他：扁桃疾患の食 事に対する満足度一経日的変化と影響因子との関連一. 山 形済生館医誌 $27: 36 \sim 29,2002$.

6) Hanif J and Frosh A : Effect of chewing gum on recovery after tonsillectomy. Auris Nasus Larynx $26: 65 \sim 68,1999$.

7) Cook JA, Murrant NJ, Evans KL, et al. : A randomized comparison of three post-tonsillectomy diets. Clin Otolaryngol Allied Sci $17: 28 \sim 31,1992$

8) Brodsky L, Radomski $\mathrm{K}$ and Gendler J : The effect of postoperative instructions on recovery after tonsillectomy and adenoidectomy. Int J Pediatr Otorhinolaryngol $25: 133 \sim 140$, 1993.

9）片山美奈子：密封小線源治療を受ける患者の看護. 患者ケ アを中心とした新しい放射線看護 (片山美奈子編). 145 頁, 医学書院, 東京, 1985 .

原稿受付：平成 18 年 5 月 31 日 原稿採択 : 平成 18 年 9 月 26 日 別刷請求先 : 今井貴夫 厂660-8511 尼崎市稲葉荘3-1-69 関西労災病院耳鼻咽喉科 